\title{
The identification of a phytohaemagglutinin in raw navy beans (Phaseolus vulgaris L.) toxic for Japanese quail (Coturnix coturnix japonica)
}

\author{
By A. T. ANDREWS AND D. J. JAYNE-WILLIAMS \\ National Institute for Research in Dairying, Shinfield, Reading $R G 2{ }_{9} A T$ \\ (Received I9 November I973-Accepted 4 February 1974)
}

\begin{abstract}
I. Simple extracts of raw navy (haricot) beans (Phaseolus vulgaris L.) known to be toxic to conventional Japanese quail (Coturnix coturnix japonica) have been fractionated and tested for toxicity by feeding to this species.

2. Of the various fractions obtained during the biochemical purification of the phytohaemagglutinin, only those possessing agglutinating activity were found to be toxic.

3. The final purification stage yielded an homogeneous protein with both agglutinating and toxic properties.
\end{abstract}

It has been known for some years (Liener, I969) that the inclusion of raw legumes in animal diets may lead to severe depression of growth and even death. It has been reported that whereas rats (Kakade \& Evans, I $965 a, b$ ), the domestic fowl (Hewitt \& Coates, 1969; Hewitt, Coates, Kakade \& Liener, 1970) and quail (Jayne-Williams \& Hewitt, I972) failed to thrive on diets containing raw navy (haricot) beans (Phaseolus vulgaris $\mathrm{L}$.), they grew well when the beans had been autoclaved.

When birds reared under germ-free conditions were fed on diets containing raw beans, however, no lethal effects were observed (Hewitt et al. 1970). Extensions of this work have clearly shown that certain components (notably coliform bacteria) of the intestinal microflora must be present before toxicity is manifest (Jayne-Williams \& Hewitt, 1972; Hewitt, Coates, Kakade $\&$ Liener, 1973; Jayne-Williams \& Burgess, 1974).

It has been suggested that protease inhibitors or phytohaemagglutinins (PHAs) may be the important toxic constituents of raw legumes (Liener, 1969), although other constituents such as cyanogenetic glycosides and amylase inhibitors have also been considered. Recent work has indicated that toxicity is associated with legume varieties rich in PHAs and with partially purified fractions rich in PHAs rather than with those rich in trypsin inhibitors (Honavar, Shih \& Liener, 1962; Kakade \& Evans, I965 $b$; Jaffé \& Lette, 1968; Hewitt et al. 1970; Evans, Pusztai, Watt \& Bauer, 1973). Other authors, however, have suggested that toxicity is separable from haemagglutinating activity (Stead, de Muelenaere \& Quicke, r966). The presence of toxic components in such an important source of protein as the legumes clearly merits a thorough investigation into the isolation, properties and mode of action of these constituents. The present paper is part of such a broad series of studies and reports the association of toxicity with the navy bean PHA through various purification stages. 
Starch gel electrophoresis at $\mathrm{pH} \mathrm{I.9}$ in the presence of $7 \mathrm{M}$-urea and $0.02 \mathrm{M}-2-$ mercaptoethanol was performed as described by Andrews (1974).

Trypsin inhibitor activity was determined according to Kunitz (1947).

Assay of haemagglutinating activity was carried out as described by Jayne-Williams (I973).

Diets were made in the manner described by Jayne-Williams \& Hewitt (1972). The raw bean fractions were incorporated (at the expense of the autoclaved meal) into a diet consisting of equal weights of a basal mixture (containing maize starch, casein, vitamins and salts) and navy-bean meal which had been autoclaved at $121^{\circ}$ for 5 min. Control diets consisted of this same diet without the addition of raw bean fractions.

All Japanese quail (Coturnix coturnix japonica) chicks were reared on a navy-beanfree diet (Shinfield quail diet, SQD; Jayne-Williams \& Hewitt, 1972) for $4 \mathrm{~d}$ after hatching before being divided into groups of eight or ten for the feeding of experimental diets.

\section{EXPERIMENTAL AND RESULTS}

\section{Expt I. Preliminary fractionation}

Navy-bean extract (X, Plate $\mathbf{r}$ ) was prepared according to Jayne-Williams \& Burgess (1974); this consisted essentially of saline extraction, followed by $\mathrm{pH}$ adjustment to $3^{\circ} \circ$ (which precipitated inactive globulins) and lyophilization of the supernatant. This lyophilized extract $(55 \mathrm{~g}$, equivalent to $\mathrm{I} \cdot 3 \mathrm{~kg}$ bean-flour starting material) was dissolved in $0.0 \mathrm{O} \mathrm{M}-\mathrm{NaH}_{2} \mathrm{PO}_{4}(4 \mathrm{l})$, placed in $38 \mathrm{~mm}$ Visking tubing and dialysed at $4^{\circ}$ for $48 \mathrm{~h}$ against $0.0 \mathrm{IM}-\mathrm{NaH}_{2} \mathrm{PO}_{4}(2 \mathrm{Ol})$ with a change of external solution after $24 \mathrm{~h}$. The precipitate which formed within the Visking tubing (A, Plate I) was collected by centrifugation at $1200 \mathrm{~g}$ for $30 \mathrm{~min}$ and mixed with the basal diet $(250 \mathrm{~g})$ and autoclaved navy-bean meal $(236 \mathrm{~g})$ to give diet A. The supernatant solution (B, Plate I) was concentrated to about $60 \mathrm{ml}$ by dialysis in $38 \mathrm{~mm}$ Visking tubing against polyethylene glycol (Carbowax $20 \mathrm{M}$, Union Carbide Ltd) and mixed with basal diet $(25 \circ \mathrm{g})$ and autoclaved navy-bean meal $(248 \mathrm{~g})$ to give diet $\mathrm{B}$. The results of feeding the diets to quail (Table I) showed that the supernatant fraction $B$, which contained most of the haemagglutinating activity, was toxic, whereas the precipitate $A$, which contained low haemagglutinating activity, was virtually without effect on quail growth.

\section{Expt 2. Ammonium sulphate precipitation}

Ammonium sulphate $(\mathrm{I} \cdot 25 \mathrm{~kg})$ was added to 41 of supernatant $B$ prepared as described in Expt I to give $50 \%$ saturation and the mixture allowed to stand overnight at $4^{\circ}$. The precipitate formed $(\mathrm{C}$, Plate $\mathrm{x})$ was collected by centrifugation at $\mathrm{I} 800 \mathrm{~g}$ for $30 \mathrm{~min}$. A further quantity of ammonium sulphate $(\mathrm{r} \cdot 0 \mathrm{~kg})$ was then added to the supernatant fraction to bring it to $80 \%$ saturation and the mixture kept at $4^{\circ}$ for $24 \mathrm{~h}$. The precipitated material (D, Plate $\mathrm{I}$ ) was collected by centrifugation at $\mathrm{I} 800 \mathrm{~g}$ for $3^{\circ} \mathrm{min}$. The two precipitated fractions (C and D) were each dissolved in about $500 \mathrm{ml}$ 
Table $\mathrm{I}$. The effects of incorporation of navy-bean fractions into diets fed to Fapanese quail

\begin{tabular}{|c|c|c|c|c|c|c|}
\hline Experiment & $\begin{array}{l}\text { Duration of } \\
\text { experiment } \\
\text { (d) }\end{array}$ & Diet & $\begin{array}{c}\text { Approx. } \\
\text { haemagglutination } \\
\text { titre* }\end{array}$ & $\begin{array}{c}\text { No. of } \\
\text { birds }\end{array}$ & $\begin{array}{l}\text { No. of } \\
\text { deaths }\end{array}$ & $\begin{array}{l}\text { Mean } \\
\text { weight }(\mathrm{g}) \text { of } \\
\text { survivors at } \\
\text { termination }\end{array}$ \\
\hline $\mathbf{I}$ & 9 & $\begin{array}{l}\text { A } \\
\text { B }\end{array}$ & $\begin{array}{l}I: 1000 \\
I: 100000\end{array}$ & $\begin{array}{l}10 \\
10\end{array}$ & $\begin{array}{l}0 \\
8\end{array}$ & $\begin{array}{l}34 \cdot 7 \\
21 \cdot 0\end{array}$ \\
\hline 2 & 7 & $\begin{array}{l}\mathrm{C} \\
\mathrm{D} \\
\mathrm{E}\end{array}$ & $\begin{array}{l}\text { I : } 1000 \\
1: 10000 \\
-\end{array}$ & $\begin{array}{l}8 \\
8 \\
8\end{array}$ & $\begin{array}{l}0 \\
8 \\
0\end{array}$ & $\frac{18.3}{19.0}$ \\
\hline 3 & 7 & $\begin{array}{l}\mathrm{F} \\
\mathrm{G}\end{array}$ & $\begin{array}{l}1 \text { : I } \\
1: 10000\end{array}$ & $\begin{array}{l}8 \\
8\end{array}$ & $\begin{array}{l}0 \\
8\end{array}$ & 18.8 \\
\hline 4 & 7 & $\begin{array}{c}\text { F } \\
\text { H } \\
\mathrm{J} \\
\mathrm{K} \\
\mathrm{L} \\
\text { ANB } \\
\text { controls }\end{array}$ & $\begin{array}{l}\text { I }: \text { I } \\
\text { I }: 1000 \\
I: 10000 \\
I: 100 \\
I: 100\end{array}$ & $\begin{array}{l}8 \\
8 \\
8 \\
8 \\
8 \\
8\end{array}$ & $\begin{array}{l}0 \\
0 \\
3 \\
1 \\
0 \\
0\end{array}$ & $\begin{array}{l}18 \cdot 1 \\
22 \cdot 3 \\
14 \cdot 4 \\
21 \cdot 1 \\
17 \cdot 0 \\
19 \cdot 4\end{array}$ \\
\hline 5 & 5 & $\begin{array}{c}\mathbf{M} \\
\mathbf{N} \\
\mathbf{P} \\
\text { ANB } \\
\text { controls }\end{array}$ & $\begin{array}{l}\text { I }: 1000 \\
I: 100000 \\
I: 100\end{array}$ & $\begin{array}{l}8 \\
8 \\
8 \\
8\end{array}$ & $\begin{array}{l}0 \\
2 \\
0 \\
0\end{array}$ & $\begin{array}{l}21 \cdot 4 \\
17 \cdot 6 \dagger \\
22 \cdot 5 \\
21 \cdot 6\end{array}$ \\
\hline
\end{tabular}

ANB, autoclaved navy-bean diet.

* Solutions adjusted to similar initial protein concentrations.

$\dagger$ Mean value for five birds: one additional bird died from injury.

At hatching, mean body-weight of quail chicks was $6.6 \mathrm{~g}$, and after $4 \mathrm{~d}$ initial rearing on Shinfield quail diet (i.e. at day 0 in Table) the mean body-weight was I I. $\mathrm{g}$.

distilled-water and dialysed free of ammonium sulphate $(25 \mathrm{~mm}$ diameter Visking tubing). The ' $80 \%$ ammonium sulphate' supernatant (E, Plate $\mathrm{r}$ ) was also placed in Visking tubing ( $38 \mathrm{~mm}$ diameter) and dialysed thoroughly against distilled-water. The three solutions were each concentrated to $50-100 \mathrm{ml}$ by dialysis against polyethylene glycol and made up into diets $C, D$ and $E$ in a manner similar to Expt I and given to quail. The results (Table I) showed that the toxicity was associated with the ' $50-80 \%$ ammonium sulphate precipitate' fraction $\mathrm{D}$.

\section{Expt 3. Adsorption onto DEAE-cellulose}

Fraction D material obtained as in Expt 2 was further treated by applying the dialysed ammonium sulphate-free solution $(500 \mathrm{ml})$ to a DEAE-cellulose column $(75 \times 270 \mathrm{~mm})$ which had been made up in 0.0 . $\mathrm{M}$-sodium phosphate buffer, $\mathrm{pH} 6 \cdot 8$. The sample was washed through with a further $\mathrm{x} 1$ of this buffer and the eluate collected (F, Plate $\mathrm{I}$ ). The column was then washed with 21 of $0^{\circ} \mathrm{I}$ M-sodium phosphate buffer, $\mathrm{pH} 6 \cdot 8$, containing $\mathrm{I} \mathrm{M}-\mathrm{NaCl}$. This procedure eluted protein material which had been adsorbed onto the column (G, Plate $\mathrm{I})$. These two fractions were dialysed against distilled-water, concentrated and made up into diets $F$ and $G$. Table I shows that toxicity was confined to $\mathrm{G}$; this also contained the haemagglutinating activity. 


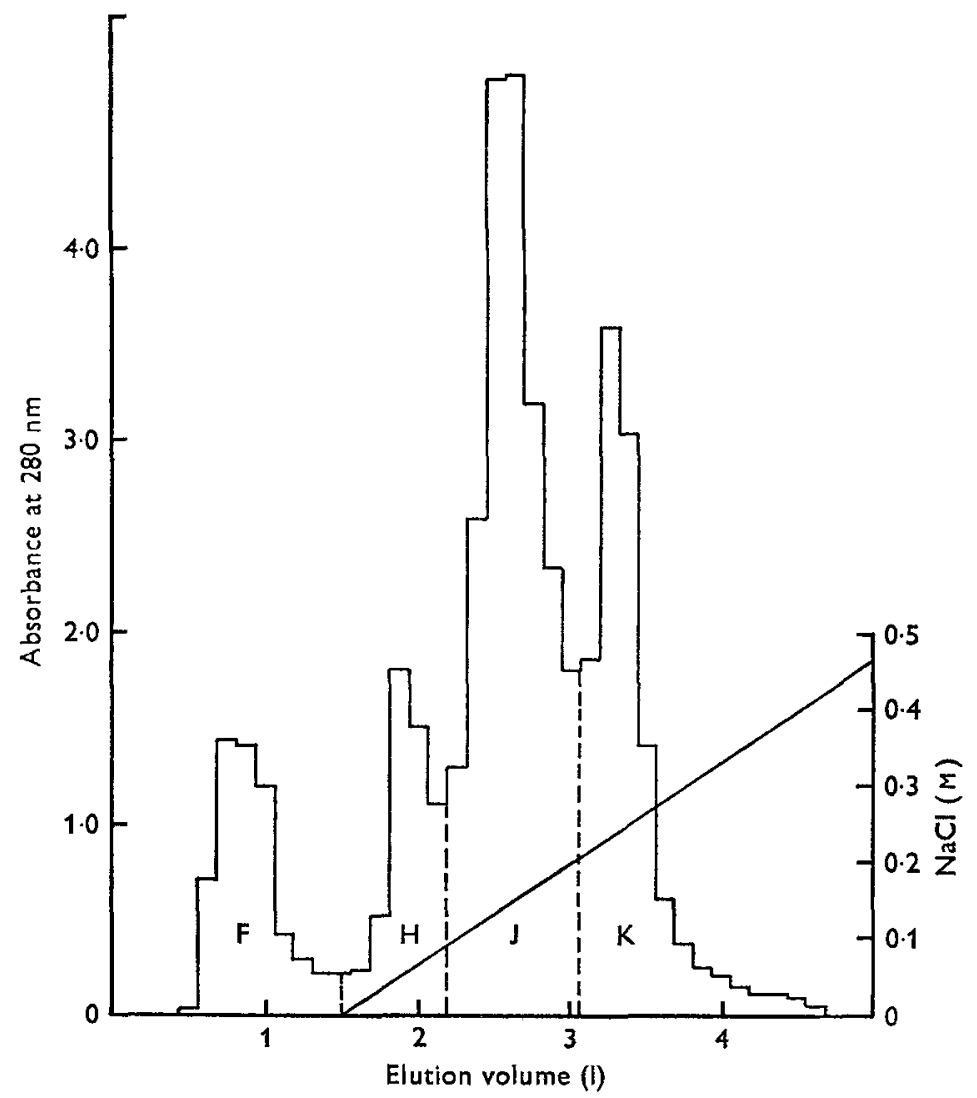

Fig. I. Results of further fractionation of navy-bean fraction D material (see p. I82) on a column $(75 \times 270 \mathrm{~mm})$ of DEAE-cellulose in $0.01 \mathrm{M}$-sodium phosphate buffer, $\mathrm{pH} 6.8$. The sample (approx. I4 $\mathrm{g}$ protein in $500 \mathrm{ml}$ of this buffer) was applied to the column and chromatographed using a $0-0.5 \mathrm{M}-\mathrm{NaCl}$ salt gradient-elution technique (Andrews, 1974). Fractions of $25 \mathrm{ml}$ were collected and pooled as indicated to give samples $\mathrm{F}, \mathrm{H}, \mathrm{J}$ and $\mathrm{K}$.

\section{Expt 4. DEAE-cellulose fractionation}

This was the same as Expt 3 except that following the application of sample D to the DEAE-cellulose column, further fractionation was achieved by use of a $0-0.5 \mathrm{M}-$ $\mathrm{NaCl}$ salt gradient-elution technique (Andrews, 1974). The separation achieved by this procedure has been previously reported (see Fig. 3, Andrews, 1974) and it was found that fraction $G$ above was further resolved (Fig. I) into three major protein peaks eluted with maxima at $\mathrm{NaCl}$ concentrations of approximately $0.05,0.15$ and $0.25 \mathrm{M}$. These peak fractions were pooled as indicated in Fig. $\mathrm{I}$ and arbitrarily labelled $\mathrm{H}, \mathrm{J}$ and $\mathrm{K}$, respectively (Plate I). Together with the material passing unadsorbed through the column (F, as in Expt 3 above) and with pooled $\mathrm{I} \mathrm{M}-\mathrm{NaCl}$ washings of the DEAE-cellulose column after the salt gradient ( $L$, Plate $\mathrm{I}$ ), these were dialysed free of salts, concentrated and made up into diets $F, H, J, K$ and $L$ in a similar manner to the previous experiments. Table I shows that most of the growth depression and toxicity was associated with the major protein peak, J, eluted with $0.15 \mathrm{M}-\mathrm{NaCl}$. By comparison with the autoclaved navy-bean diet controls, neither $\mathrm{H}$ nor $\mathrm{K}$ gave 


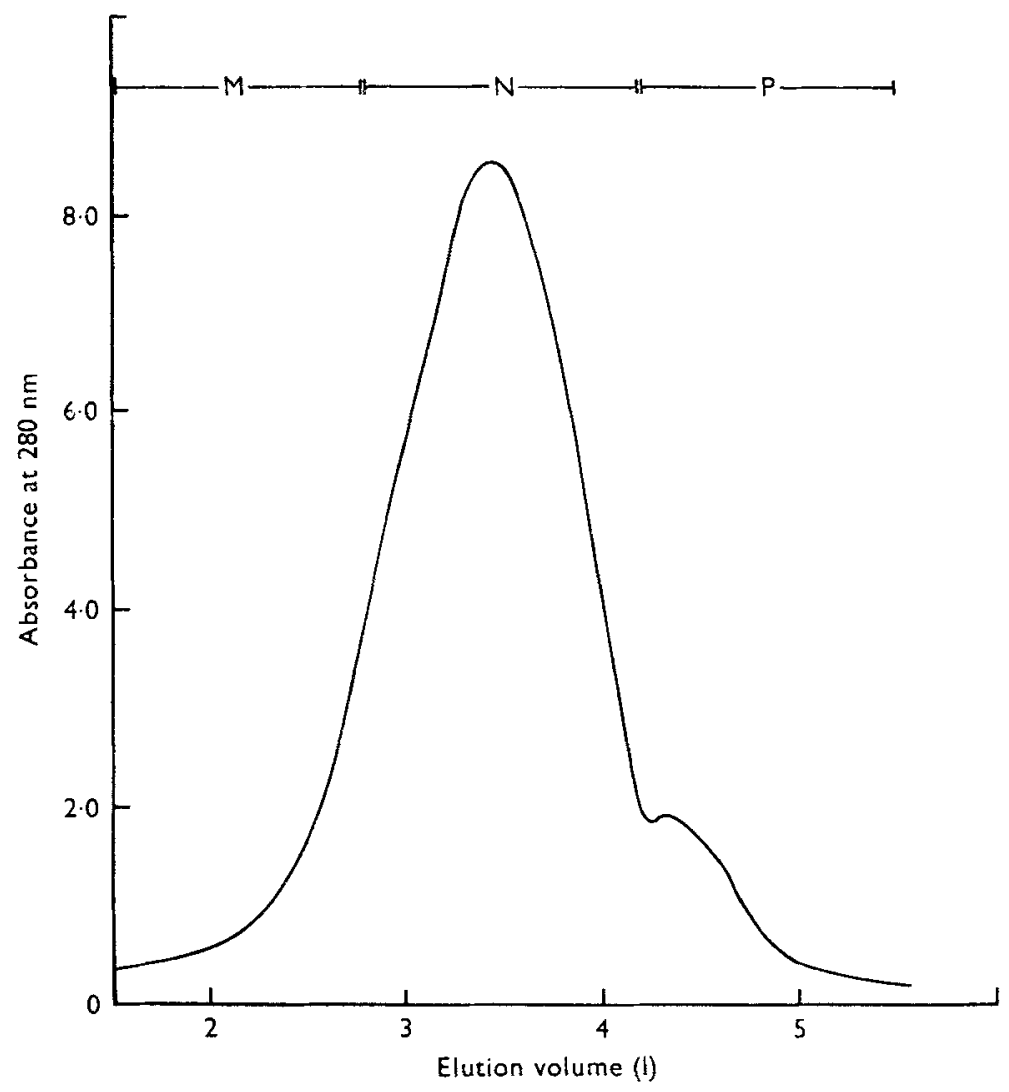

Fig. 2. Results of gel filtration of navy-bean fraction J (see p. 184) on a column ( $96 \times 900 \mathrm{~mm}$ ) of Sephadex G-200 in $0.2 \mathrm{M}$-sodium phosphate buffer, $\mathrm{pH} 6.8$, containing $0.2 \mathrm{M}-\mathrm{NaCl}$. The sample (about $8 \mathrm{~g}$ of protein) was applied in approximately $200 \mathrm{ml}$ of this buffer and fractions of $25 \mathrm{ml}$ were collected at a flow rate of $100 \mathrm{ml} / \mathrm{h}$. Fractions comprising the leading and trailing portions of the peak and the main portion were pooled as indicated to give samples $\mathrm{M}, \mathrm{N}$ and $\mathrm{P}$.

rise to depressed growth rates even though both were probably contaminated with J due to incomplete resolution on the column. The single fatality in the group of birds given $\operatorname{diet} \mathrm{K}$ was probably a non-specific death.

\section{Expt 5. Gel filtration}

Fraction J material from a repeat of Expt 4 was further treated by gel filtration through a column of Sephadex G-200, as described by Andrews (1974). A single major protein peak was eluted (Fig. 2), but since leading fractions contained traces of minor components these were pooled as indicated (Fig. 2) to give material M (Plate I). The bulk of the protein peak contained the highly purified phytohaemagglutinin (Andrews, 1974) and fractions containing this were combined to give sample $\mathrm{N}$ (Plate I). Fractions at the trailing edge of the peak and the next 21 of eluate, which contained traces of faster-moving electrophoretic components, were combined to give $\mathrm{P}$ (Plate $\mathrm{I}$ ). The three batches of solution $\mathrm{M}, \mathrm{N}$ and $\mathrm{P}$ were each dialysed, 
concentrated and made up into diets $\mathrm{M}, \mathrm{N}$ and $\mathrm{P}$ as previously described and fed for $5 \mathrm{~d}$ to groups of eight quail chicks. It may be seen from Table I that death and growth depression were confined to the birds on diet $\mathrm{N}$, which contained most of the phytohaemagglutinin. The lack of toxicity of fractions $L, M$ and $P$, which may appear from Plate $\mathbf{I}$ to be similar to $\mathrm{N}$, is related to the amounts of material in these fractions. Protein concentrations were adjusted to give a suitable intensity of electrophoretic patterns and these showed that $\mathrm{L}, \mathrm{M}$ and $\mathrm{P}$ each consisted largely of PHA accompanied in each instance by minor impurities. However, the total amount of material in each of these fractions was quite small so that toxicity due to the PHA contents was not manifest at these low dose levels. No such minor impurity bands were visible in fraction $\mathrm{N}$, however, which thus indicated that toxicity was associated with the PHA.

With only semi-quantitative assay procedures available for the measurement of agglutinating activity, the over-all recovery from the initial extract of PHA in fraction $\mathrm{N}$ was difficult to assess accurately but was considered to be of the order of $50-60 \%$.

The purified PHA constituting $\mathrm{N}$, and also purified navy-bean component I (Andrews, 1974), which is the principal constituent of fraction A above, were both devoid of trypsin inhibitor activity.

\section{DISCUSSION}

Past work on the toxicity of raw legumes has tended to concentrate on studies of the effects produced by incorporating varying proportions of the legume into animal diets or of the effects of different varieties of legume, and correlating the observed growth depression or deaths with a measurable biochemical activity (e.g. trypsin inhibition, haemagglutination, etc.). Some authors, however, have carried the investigation a stage further by applying preliminary fractionation procedures and examining the effects of various fractions added to experimental diets; these studies have suggested that whereas trypsin inhibitor activity may lead to enlargement of the pancreas and some growth depression, toxicity is generally confined to fractions containing agglutinating activity. With legumes like Phaseolus vulgaris, such fractionation procedures with the black bean and red kidney bean (Honavar et al. 1962) and with the navy bean (Kakade \& Evans, $\mathrm{I}_{96} b$ ) have implicated the PHA as the toxic component. Stead et al. (I966), however, suggested that toxicity and PHA activity are separable, although, for toxicity testing, they used intraperitoneal injection into rats, which may not be strictly comparable with oral administration. The products of such simple fractionation schemes are not homogeneous, however, and in composition often resemble the initial extract used in the present work, in which, under suitable conditions, at least twenty-four individual protein bands have been observed on starch gel electrophoresis. On the basis of the lethality or growth-inhibiting effects of such extracts or fractions, therefore, no definite conclusion can be drawn with regard to the toxicity of the PHAs.

Highly purified concanavalin A, the PHA from the jack bean (Canavalia ensiformis), has recently been shown to be toxic to quail (Jayne-Williams, 1973) but we have found no reports of the results of incorporating highly purified PHAs from varieties of Phaseolus vulgaris into experimental diets, although highly purified PHAs from the 
red kidney bean (Rigas \& Johnson, 1964), the wax bean (Takahashi, Ramachandramurthy \& Liener, 1967), the black bean (Jaffé \& Hannig, 1965) and the navy bean (Andrews, 1974) have been prepared and characterized in biochemical terms.

The present paper reports the results of incorporation into experimental diets of navy-bean PHA at various stages of purification, starting with a simple saline extract from which some inactive protein had been removed by $\mathrm{pH}$ adjustment. This extract had previously been shown to contain the bulk of the toxicity to quail and also most of the haemagglutinating activity (Jayne-Williams \& Burgess, 1974). During subsequent purification stages the toxicity was invariably found associated with the fractions containing the PHA. In Expt 5, this PHA was the only protein component detectable in the toxic fraction $\mathrm{N}$, and this has been shown by electrophoresis, ultracentrifugal analysis, $\mathrm{N}$-terminal analysis and gel filtration to be a single homogeneous glycoprotein (Andrews, 1974) with a molecular weight of about II 4000 in the native state. The association of oral toxicity to quail with the PHA indicates that, in the navy bean, toxicity and agglutinating activity are associated with the same molecule, as in the case of concanavalin A from the jack bean (Jayne-Williams, 1973), and are not separable from one another.

While this study identifies the PHA as the major toxic factor in the navy bean, it is possible that other components also contribute to a lesser extent towards the total toxicity. Evans et al. (I973) have reported growth inhibition of rats given a diet containing a navy-bean fraction with very low trypsin-inhibitor activity but high in lymphocyte-stimulating activity and haemagglutinating activity. Although these authors state that their results were not unequivocal owing to the small numbers of experimental animals used, and also because the fraction used by them probably consisted of at least four components (as discussed by Andrews, 1974), their findings nevertheless support our contention that navy-bean PHA possesses oral toxicity. The apparent lack of correlation between toxicity and the levels of PHA activity reported by previous workers (Kakade \& Evans, $1965 b$ ), together with the apparent separation of toxicity from PHA activity, may be at least in part a reflection of the undoubtedly complicated mechanism giving rise to toxicity, in which the gut flora is implicated (for discussions see Jayne-Williams \& Hewitt, 1972; Hewitt et al. 1970, 1973; JayneWilliams, I973; Jayne-Williams \& Burgess, 1974).

The authors wish to thank Mr M. D. Taylor, Mr P. Clarricoates, Mrs J.E. D. Hermon, Mrs D. Bathe and Miss M. Cook for skilful technical assistance.

\section{REFERENCES}

Andrews, A. T. (1974). Biochem. $\mathcal{F}$. (In the Press.)

Evans, R. J., Pusztai, A., Watt, W. B. \& Bauer, D. H. (1973). Biochim. biophys, Acta 303, 175.

Hewitt, D. \& Coates, M. E. (1969). Proc. Nutr. Soc. 28, 47A.

Hewitt, D., Coates, M. E., Kakade, M. L. \& Liener, I. E. (1970). Proc. Nutr. Soc. 29, 15 A.

Hewitt, D., Coates, M. E., Kakade, M. L. \& Liener, I. E. (1973). Br. F. Nutr. 29, 423.

Honavar, P. M., Shih, C.-V. \& Liener, I. E. (1962). F. Nutr. 77, 109.

Jaffé, W. G. \& Hannig, K. (1 965). Archs Biochem. Biophys. ro9, 80.

Jaffé, W. G. \& Lette, C. L. V. (1968). Y. Nutr. 94, 203.

Jayne-Williams, D. J. (1973). Nature New Biol. 243, 150. 
British Fournal of Nutrition, Vol. 32, No. I

Plate I

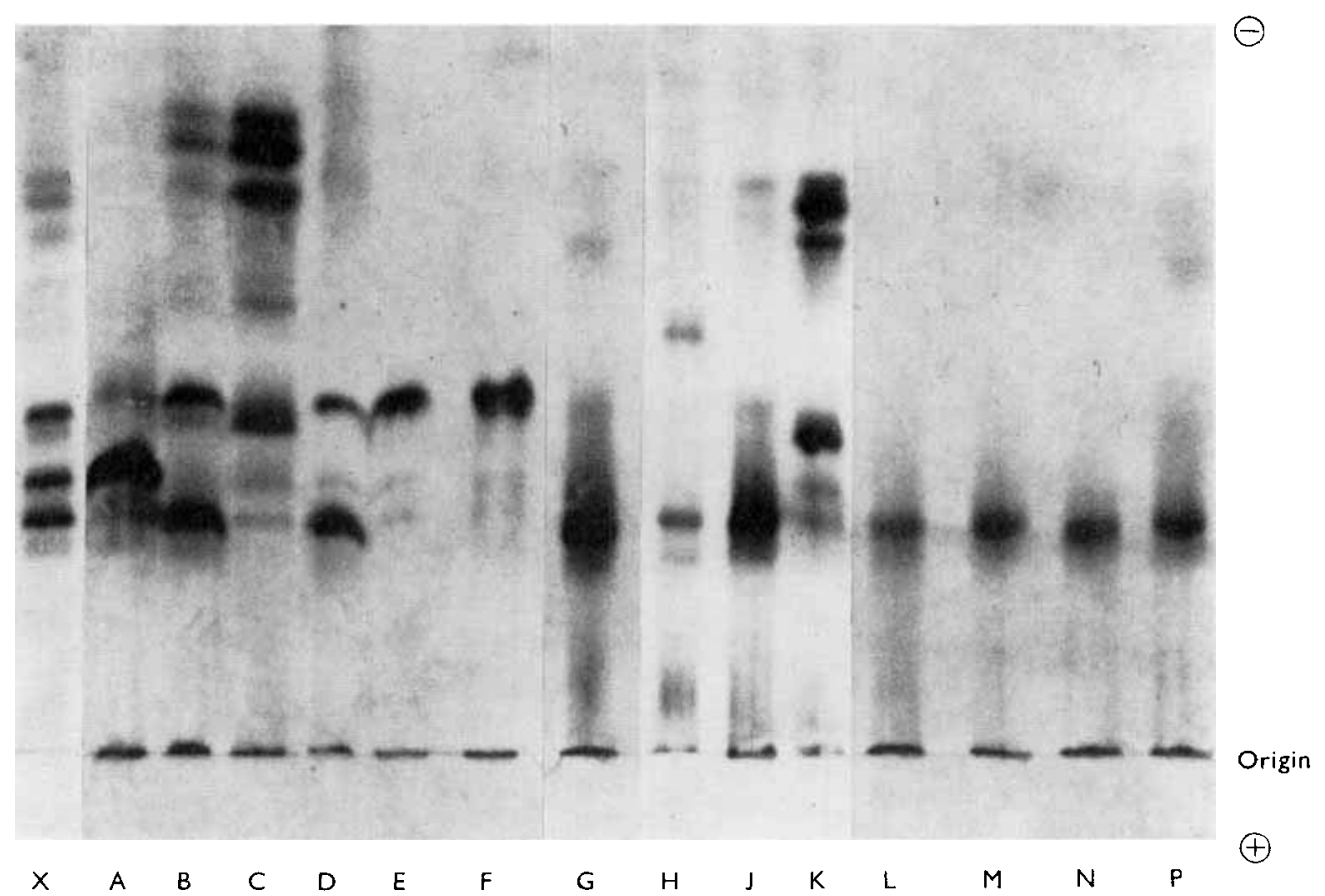

A. T. ANDREWS AND D. J. JAYNE-WILLIAMS 
Jayne-Williams, D. J. \& Burgess, C. D. (1974). $\mathcal{~}$. appl. Bact. (In the Press.)

Jayne-Williams, D. J. \& Hewitt, D. (1972). F. appl. Bact. 35, $33 \mathrm{I}$.

Kakade, M. L. \& Evans, R. J. (1965a). Br. F. Nutr. 19, 269.

Kakade, M. L. \& Evans, R. J. (1965b). F. agric. Fd Chem. 13, $45^{\circ}$.

Kunitz, M. (1947). F. gen. Physiol. 30, 29 I.

Liener, I. E. (1969). In Toxic Constituents of Plant Foodstuffs p. 409 [I. E. Liener, editor]. New York and London: Academic Press.

Rigas, D. A. \& Johnson, E. A. (r964). Ann. N.Y. Acad. Sci. rr3, 800.

Stead, R. H., de Muelenaere, H. J. H. \& Quicke, G. V. (I966). Archs Biochem. Biophys. I13, 703.

Takahashi, T., Ramachandramurthy, P. \& Liener, I. E. (1967). Biochim. biophys. Acta 133, I23.

\section{EXPLANATION OF PLATE}

Starch gel electrophoresis patterns of navy-bean fractions (see text). Geis were run at $\mathrm{pH} \mathrm{I}^{\prime} \mathrm{9}$ in the presence of $7 \mathrm{M}$-urea and $0.02 \mathrm{M}-2$-mercaptoethanol. Samples of lyophilized-extract starting material (X) and fractions A-P were applied as indicated. It should be noted that these gel patterns are purely qualitative since concentrations of fractions were adjusted to give suitable loadings on the gels, so that the intensity of a particular band in one fraction should not be compared with that of the same band in other fractions. 